\title{
YOUTUBE SEBAGAI MEDIA PEMBELAJARAN PENCEGAHAN DAMPAK PENYEBARAN VIRUS COVID19
}

\author{
Oleh: \\ Ariyanti Sarwono, Betanti Ridhosari, Imroatus Sholikhah, I Wayan Koko Suryawan* \\ Program Studi Teknik Lingkungan, Fakultas Perencanaan Infrastruktur, Universitas Pertamina \\ i.suryawan@universitaspertamina.ac.id
}

\begin{abstract}
Abstrak
Anak-anak merupakan salah satu masyarakat yang rentan terhadap penularan virus selama pandemi COVID-19. Untuk mencegah hal tersebut maka dilakukan pemberian edukasi ke masyarakat berupa penyuluhan melalui media YouTube. Tujuan dari penyuluhan ini adalah memberikan edukasi protocol kesehatan dalam menanggulangi virus COVID-19 dan pengurangan dampak lingkungan yang dikhususkan kepada masyarkaat sasar. Masyarakat sasar dalam penyuluhan ini adalah anak-anak $(n=34)$ yang berada dalam kelompok program "Temani Aku Belajar Universitas Pertamina". Dari hasil pemberian video layanan masyarakat, anak-anak sudah melakukan protocol kesehatan dengan baik seperti mencuci tangan, menggunakan masker, dan membuang sampah masker. Namun kebiasaan bermain diluar rumah masih menjadi masalah anak-anak sehingga hal ini perlu ditekan.
\end{abstract}

Kata Kunci: COVID19, Protokol Kesehatan, Lingkungan, Anak-anak

\section{Abstract}

Children are one of the communities that are vulnerable to transmission of the virus during the COVID-19 pandemic. To prevent this, education is provided to the public in the form of counselling through YouTube media. This counselling aims to provide knowledge on health protocols in overcoming the COVID-19 virus and reducing environmental impacts directed to target communities. In this counselling, the target communities are children $(n=34)$ in the program group "Temani Aku Belajar" at Universitas Pertamina. The results of the provision of community service videos showed that children had implemented health protocols such as washing hands, using masks, and disposing of mask waste properly. On the contrary, the habit of playing outside is still an issue for children, and this needs to be suppressed.

Keywords: COVID19, Health Protocol, Environment, Children

\section{PENDAHULUAN}

Pada Desember 2019, beberapa kasus pneumonia dengan etiologi yang tidak diketahui, dilaporkan di Wuhan, Cina. Pada akhir Januari 2020, Organisasi Kesehatan Dunia (WHO) telah menyatakan wabah tersebut sebagai masalah serius secara global. Penyakit yang kini dikenal sebagai penyakit coronavirus 2019 (COVID-19) dapat menyebabkan sindrom pernafasan akut parah coronavirus 2 (SARS-CoV-2).

Kasus COVID-19 pertama di Jakarta tercatat pada 3 Maret 2020, dari seorang pasien yang melakukan kontak dengan warga negara Jepang (yang kemudian dipastikan positif COVID-19). Pemprov DKI Jakarta menggalakkan social distancing untuk menekan penyebaran COVID-19. Aturan ini diberlakukan sejak 10 April 2020 berdasarkan Peraturan Gubernur DKI Jakarta No 33/2020. Peraturan tersebut mewajibkan penutupan sekolah, fasilitas umum seperti mal, dan banyak tempat lain yang berpotensi menjadi tempat berkumpulnya orang di lokasi yang sama. Penutupan sekolah dan penerapan belajar dari rumah sangat penting dalam pencegahan penyebaran COVID-19 di lingkungan provinsi DKI Jakarta.

Anak-anak, dari segala usia, sensitif terhadap COVID-19, namun jenis kelamin tidak memempengaruhi penyebaran virus ini secara signifikan (Dong et al., 2020). Anak-anak kecil, terutama bayi, rentan terhadap infeksi virus COVID-19. Pencegahan terhadap penularan virus perlu diberikan kepada anak-anak di kota Jakarta, mengingat resiko penyebaran virus ini sangat tinggi. Untuk itu diperlukan suatu upaya pemberian iklan layanan masyarakat mengenai tata cara melakukan protokol kesehatan kepada anak-anak khususnya di kota Jakarta. Pemberian video dapat dilakukan melalui platform media sosial berbasis video YouTube.

YouTube adalah situs web kedua yang paling banyak dikunjungi dan mesin pencari terbesar kedua di dunia (Stokel-Walker, 2020). Secara khusus, YouTube, dengan lebih dari satu miliar pengguna di seluruh dunia dan lebih dari 100 juta video, menjadi sumber informasi kesehatan yang semakin penting (Covolo et al., 2017), dan 
memiliki kapasitas untuk mempengaruhi penggunanya. Contoh penerapan Youtube dalam dunia kesehatan adalah kebiasaan vaksinasi (Covolo et al., 2017) atau pengambilan keputusan pasien mengenai pembelian obat (Cuan-Baltazar et al., 2020).

Dengan adanya layanan video ini, diharapkan tertanamnya wawasan anak-anak untuk menerapkan protokol kesehatan sehingga mengurangi dampak lingkungan. Dampak lingkungan yang dapat ditimbulkan dari aktifitas sehari-hari adalah timbulan sampah infeksius dari penggunaan alat pelindung diri. Timbulan sampah yang dihasilkan dari alat pelindung diri diperkirakan sebesar 129 miliar masker dan 65 miliar sarung tangan setiap bulan (Prata et al., 2020). Tujuan penyuluhan ini adalah untuk memberikan edukasi pencegahan penularan virus COVID-19 dan pengurangan dampak lingkungan yang dikhususkan kepada anak-anak, dan melihat hasil respon masyarakat sasar melalui media google form.

\section{METODE}

Kegiatan ini dilaksanakan dengan melakukan penyuluhan secara daring kepada masyarakat sasar. Pembuatan konten video dilakukan dengan memilih anak-anak sebagai pemeran agar menarik minat masyarakat sasar. Masyarakat sasar dalam kegiatan ini adalah anak-anak sekolah dasar yang berada di kawasan Rawa Simprug, Jakarta Selatan. Jumlah responden melalui pembuatan iklan layanan ini sebanyak 34 anak. Adapun tahapan kegiatan penyuluhan ini dapat dilihat pada Gambar 1. Masyarakat sasar dalam penyuluhan ini adalah anak-anak yang mengikuti program "Temani Aku Belajar" yang dikelola oleh Lembaga Penelitian, Pengabdian Masyarakat dan Inovasi (LPMMI), Universitas Pertamina.

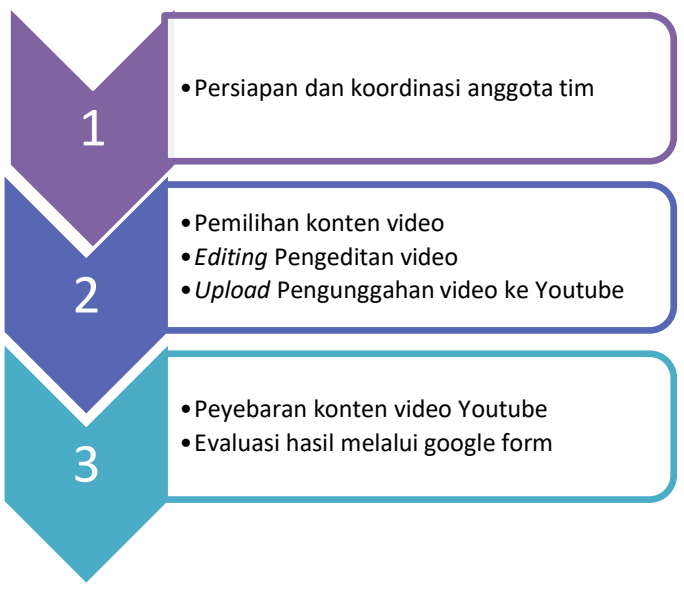

Gambar 1. Tahapan pelaksanaan penyuluhan melalui media Youtube

\section{HASIL DAN PEMBAHASAN}

\section{Konten Video}

Secara garis besar, bentuk video layanan masyarakat dapat dilihat pada tautan https://www.youtube.com/watch?v=b 7I dURnD4.

Pembuatan konten video dilakukan semenarik mungkin dengan memberikan gambar animasi. Kalimat pembuka juga disajikan untuk menyambut anak-anak dengan baik. Gambar video pembukaan dapat dilihat pada Gambar 2

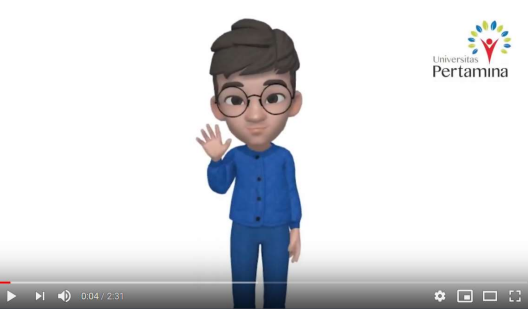

Gambar 2. Animasi pembuka penyuluhan protocol COVID19 kepada anak-anak melalui media Youtube

Video dilanjutkan dengan pembukaan pemberian tata cara mencuci tangan dengan benar dan menggunakan sabun (Gambar 3). Cuci tangan dilakukan dengan membasahi seluruh tangan dengan air bersih mengalir, kemudian menggosokkan sabun ke telapak, punggung tangan, sela jari, dan bagian bawah kuku-kuku. Lalu dilanjutkan dengan membilas tangan dengan air bersih mengalir dan dikeringkan. Setelah tata cara cuci tangan ditanyangkan, video dilanjutkan dengan tata cara memakai masker dengan benar, dimana mulut dan hidung harus tertutup dan tidak terdapat sela antara wajah dan masker (Gambar 4).

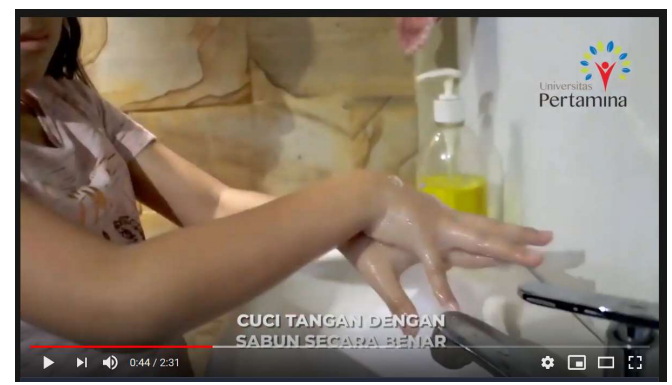

Gambar 3. Tangkap layar video cuci tangan dengan sabun secara benar 


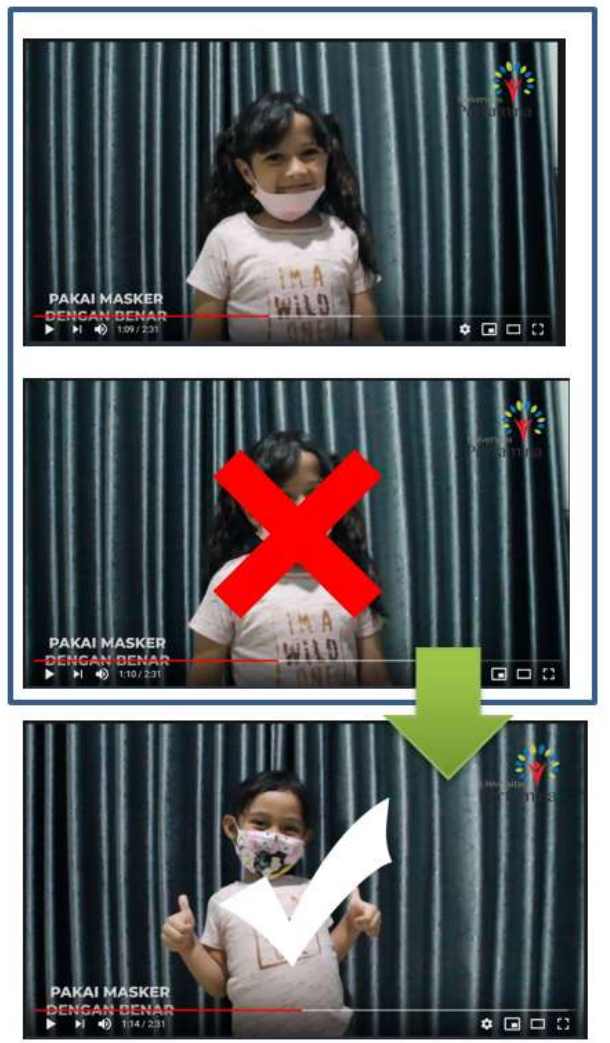

Gambar 4. Tangkap layar video memakai masker dengan benar

Timbulan sampah domestik saat pandemi COVID-19 memberikan resiko dampak lingkungan (Suryawan et al., 2021). Peningkatan diperkirakan timbulan sampah infeksius diakibatkan oleh penggunaan alat pelindung diri selama pandemi COVID-19. Salah satunya yang paling banyak ditimbulkan adalah masker sekali pakai. Untuk mencegah risiko penularan di media sampah sampah, masker harus dikemas dengan baik. Dalam video ini, masker habis pakai digunting terlebih dahulu kemudian dibungkus plastik dengan aman. Tidak hanya itu, plastik untuk membungkus sampah khusus alat pelindung diri harus diikat dengan baik (Ardiana et al., 2020). Sedangkan pewadahan sampah juga menggunakan wadah yang kuat dan tidak bocor.
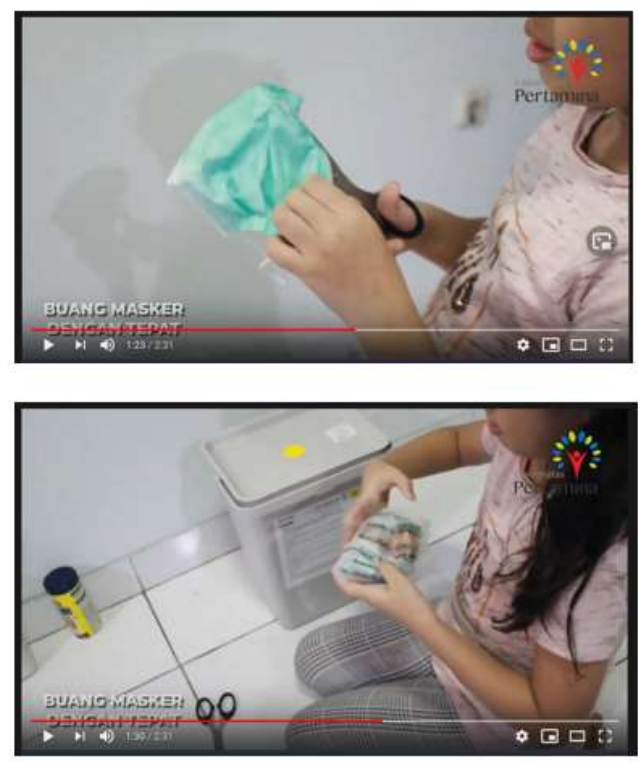

Gambar 5. Tangkap layar video membuang masker bekas dengan benar

Apabila berada di ruang tertutup dan tidak memakai masker, maka diwajibkan untuk memperhatikan etika bersin dimana harus menggunakan siku untuk menutupi mulut dan hidung (Gambar 6). Sedangkan saat bermain, anak-anak juga diwajibkan untuk tetap menjaga jarak (Gambar 7). Selain itu membersihkan peralatan makan perlu dilakukan sebelum digunakan (Gambar 8).

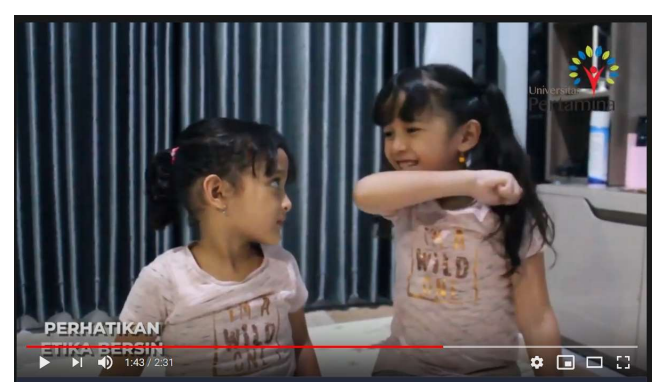

Gambar 6. Tangkap layar video etika bersin

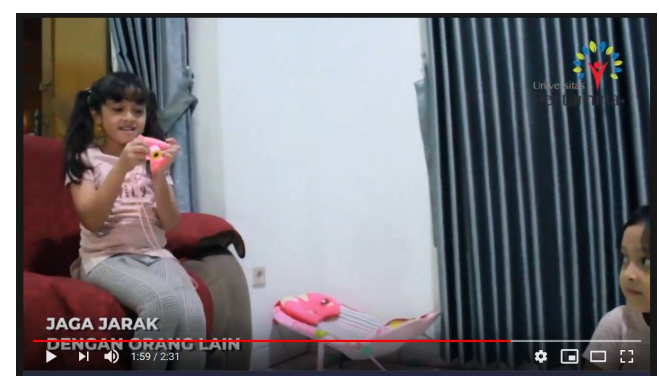

Gambar 7. Tangkap layar video menjaga jarak 


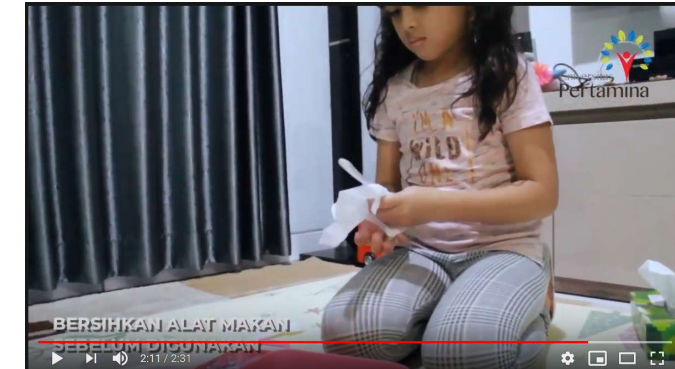

Gambar 8. Tangkap layar video membersihkan alat makan

\section{Feedback}

Pemberian feedback dilakukan dengan media google form yang dikemas seperti Gambar 9. Sebanyak $97 \%$ responden mengisi sendiri google form, dan hanya $3 \%$ yang mengisi sembari ditemani orang tua. Penyebaran kuisioner dilakukan oleh panitia melalui sosial media. Hasil kuisioner dapat dilihat pada Tabel 1. Hasil kuisioner menunjukkan bahwa anak-anak yang mengisi kuisioner sebagian besar adalah laki-laki. Anak-anak sudah melakukan gerakan mencuci tangan secara rajin dengan memakai sabun. Anak-anak juga telah menggunakan masker di kegiatan sehari-hari. Sebesar $97 \%$ responden menyebutkan sudah membuang sampah masker dengan baik. Sedangkan $9.1 \%$ responden menyatakan tidak pernah membuang masker. Hal ini dikarenakan pemakaian masker yang bisa digunakan kembali. Terlihat frekuensi pembuangan masker juga cukup tinggi yaitu 1-2 kali dalam sehari. Hal ini disebabkan sebagian responden menggunakan masker satu kali pakai. Hasil kuisioner juga memperlihatkan bahwa anakanak masih melakukan kegiatan di luar rumah walaupun sekolah ditutup. Sebagian kecil anakanak masih tidak menjaga jarak saat bermain di luar rumah.

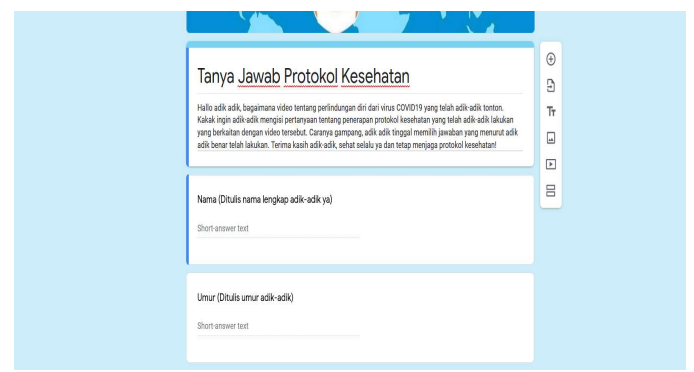

Gambar 9. Tangkap layar google form yang diberikan kepada masyarakat sasar

Tabel 1. Hasil kuisioner melalui google form mengenai protokol kesehatan selama pandemic COVID19

\begin{tabular}{ll}
\hline No & \multicolumn{1}{c}{ Pertanyaan } \\
\hline 1 & Jenis kelamin adik? \\
\hline $2 \quad$ Sudahkah adik-adik rajin mencuci tangan? & Jawaban \\
& \\
& Apakah adik-adik mencuci tangan memakai \\
& Sabun?
\end{tabular}




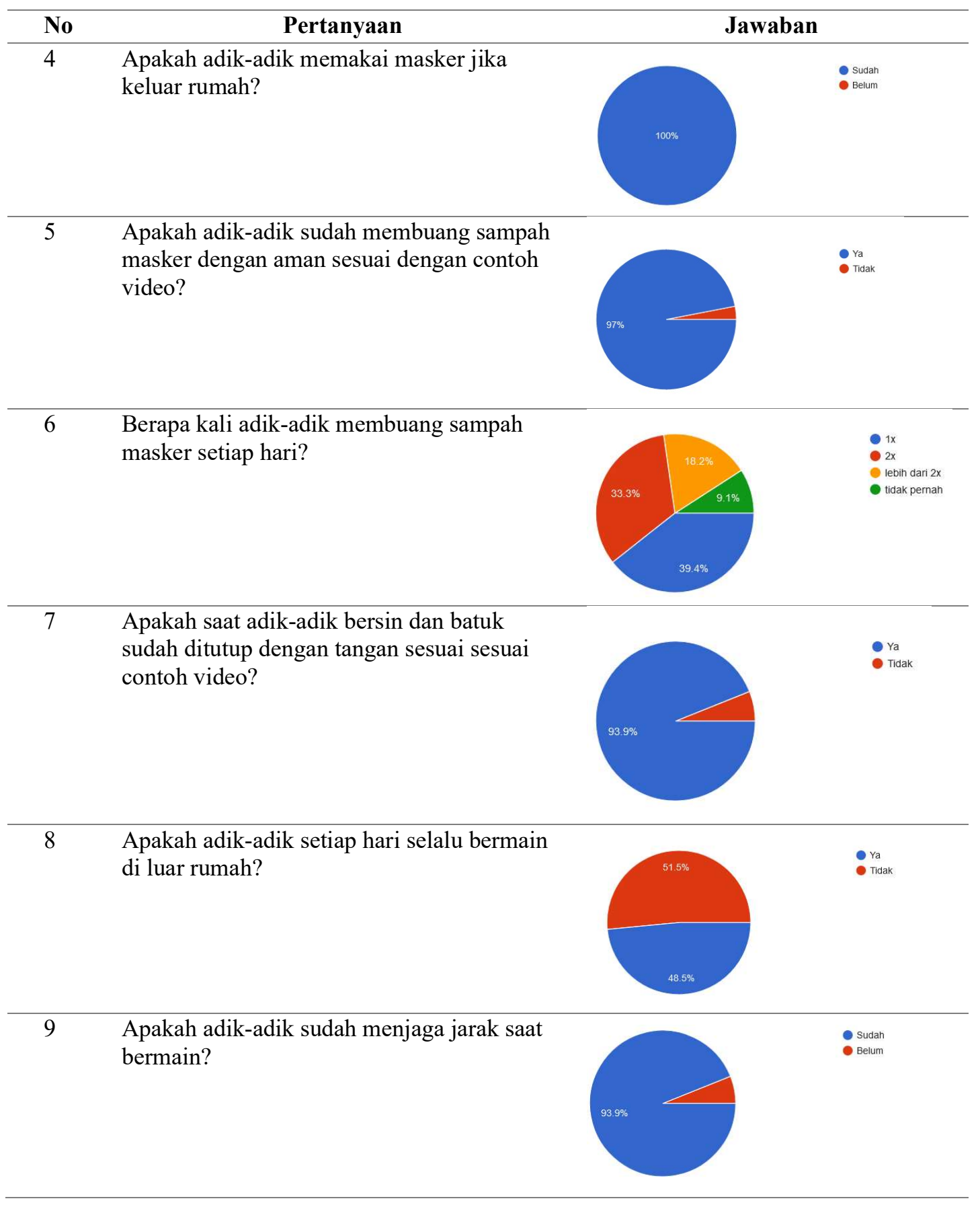

\section{SIMPULAN DAN SARAN}

\section{Simpulan}

Hasil pemberian video layanan masyarakat memberikan gambaran terhadap anak-anak untuk tetap menjaga protokol kesehatan. Secara menyeluruh anak-anak sudah memahami tata cara mencuci tangan, memakai masker, dan membuang sampah bekas pelindung diri dengan baik. Perhatian mendalam harus diberikan kepada kebiasan tetap bermain diluar rumah serta masih adanya kebiasaan tidak menjaga jarak saat bermain.

\section{Saran}


Diperlukan suatu layanan masyarakat kepada anak-anak yang lebih menyeluruh terutama untuk mengurangi kebiasaan bermain diluar rumah. Penelitian efektivitas penutupan sekolah selama masa pandemi untuk mengurangi kebiasaan berkumpul perlu diuji dalam bentuk penelitian.

\section{DAFTAR PUSTAKA}

Ardiana, N.; Suryawan, I. W. K., Ridhosari, B. (2020). Challenges for hazardous waste management related to covid-19 pandemic at train station. International Journal of Advanced Trends in Computer Science and Engineering ; 9(5):8364-8370

Covolo, L., Ceretti, E., Passeri, C., Boletti, M., \& Gelatti, U. (2017). What arguments on vaccinations run through YouTube videos in Italy? A content analysis. Human vaccines \& immunotherapeutics, 13(7), 1693-1699.

Cuan-Baltazar, J. Y., Muñoz-Perez, M. J., Robledo-Vega, C., Pérez-Zepeda, M. F., \& Soto-Vega, E. (2020). Misinformation of COVID-19 on the internet: infodemiology study. JMIR public health and surveillance, 6(2), e18444.

Dong, Y., Mo, X., Hu, Y., Qi, X., Jiang, F., Jiang, Z., \& Tong, S. (2020). Epidemiology of COVID-19 among children in China. Pediatrics, 145(6).

Prata, J. C., Silva, A. L., Walker, T. R., Duarte, A. C., \& Rocha-Santos, T. (2020). COVID-19 pandemic repercussions on the use and management of plastics. Environmental Science \& Technology, 54(13), 7760-7765.

Stokel-Walker, C. (2020). Covid-19: The doctors turned YouTubers. Bmj, 369.

Suryawan, I. W. K., Rahman, A., Septiariva, I. Y., Suhardono, S., \& Wijaya, I. M. W. (2021). Life Cycle Assessment Of Solid Waste Generation During And Before Pandemic Of Covid-19 In Bali Province. Journal of Sustainability Science and Management, 16(1), 11-21. 